\title{
Host Range Studies of Rice Sheath Blight Fungus Rhizoctonia solani (Kuhn)
}

\author{
B.T. Nagaraj ${ }^{1}$, Gururaj Sunkad ${ }^{1}$, D. Pramesh ${ }^{2 *}$, M.K. Naik ${ }^{1}$ and M.B. Patil ${ }^{1}$ \\ ${ }^{1}$ Department of Plant Pathology, University of Agricultural Sciences, \\ Raichur-584 104, Karnataka, India \\ ${ }^{2}$ Rice Pathology Laboratory, All India Co-ordinated Rice Improvement Programme, \\ Agricultural Research Station, Gangavathi-583 227, Karnataka, India \\ *Corresponding author
}

\begin{tabular}{|l|l|}
\hline \multicolumn{1}{c|}{ A B S T R A C T } \\
\cline { 2 - 2 } \multicolumn{1}{l|}{$\begin{array}{l}\text { Key word s } \\
\text { Rice, Rhizoctonia } \\
\text { solani, Sheath blight, } \\
\text { Weeds, Sclerotia, } \\
\text { Host range. }\end{array}$} & $\begin{array}{l}\text { The pathogen, Rhizoctonia solani has a wide host range infecting crops and weed } \\
\text { plants. In order to find out the host range of } R \text {. solani causing rice sheath blight, 26 } \\
\text { plant species were selected which are commonly found in rice growing ecosystem. } \\
\text { These plant species belonging to six families were grown and inoculated with } \\
\text { fungus in glasshouse condition. Twenty five plant species found infected and one } \\
\text { plant species devoid of infection. Diseased tissues of plants species belong to } \\
\text { family Graminaceae, Cyperaceae produced typical symptoms of sheath blight. The } \\
\text { Aungus produced typical root rot and bark peeling symptoms in plant species }\end{array}$ \\
\hline $\begin{array}{l}\text { Accepted: } \\
\text { 28 September 2017 } \\
\text { Available Online: } \\
\text { 10 November 2017 }\end{array}$ & $\begin{array}{l}\text { belongs to family, Leguminaceae, Malvaceae, Amaranthaceae, The fungus not } \\
\text { able to infect one weed species belongs to family Fabaceae, Indian joint vetch } \\
\text { (Aeschynomene indica). }\end{array}$ \\
\hline \hline
\end{tabular}

Introduction

Sheath blight disease of rice is caused by the fungus Rhizoctonia solani Kuhn (teleomorph Thanetophorus cucumeris Frank Donk.). The $R$. solani is cosmopolitan fungus with a very wide host range and attacks large number of crop plants and weeds (Ou, 1972). At one stage, it was claimed that there is hardly any plant species, which cannot be infected by $R$. solani (Singh et al., 1999). Kozaka (1961) from Japan recorded 188 species of plants from 32 families that can be infected by this fungus. This fungus causes banded leaf and sheath blight in maize, rice and sorghum, damping-off in cotton, aerial blight and stem rot in mungbean and soybean, sheath rot in sugarcane, heart rot in cabbage, black scurf and sprout canker in potato and foliar blights of fruits and plantation crops (Tangonan and Quebral, 1992). The fungus has a worldwide distribution (Ogoshi, 1987) and isolates of $R$. solani are highly variable in aggressiveness. The host range of $R$. solani is extensive. The pathogen is capable of causing seedling damping-off, root rot, collar rot, stem canker, crown rot, bud and fruit rots, and foliage blight on a variety of susceptible agriculturally important crops (Baker 1970; Anderson 1982) like soybean (Glycine max L. Merr., Liu and Sinclair, 1991), cotton (Gossypium hirsutum L.; Brown and 
McCarter, 1976), canola (Brassica campestris L.; Yitbarek et al., 1987), wheat (Triticum aestivum L.; Wiseman et al., 1995), beet (Beta vulgaris L.; Carling et al., 1987), potato (Solanum tuberosum L. subsp. tuberosum; Escande and Echandi 1991) and rosemary (Rosemarinus officinalis L.; Conway et al., 1997). Rhizoctonia solani also infects a number of turfgrass species (Couch, 1995).

Several weeds like Cyperus rotundus, Cyperus difformis, Cynodon dactylon, Echinochloa colonum, Commelina obliqua and Amaranthus viridis were also identified as collateral hosts and the pathogen perpetuates in these hosts in absence of rice plants (Acharya and Sengupta, 1998). The host range studies of $R$. solani indicated that it was successfully infected 14 different plant species belonging to three families. This proves that weeds and plants serve as collateral hosts and helped in the spread of the disease in next season (Srinivas et al., 2014). The present investigation is carried out for the identification of host range of $R$. solani causing rice sheath blight. Hence, there is a need to collect information on the off season survival of $R$. solani in rice ecosystem on different plant species. Considering the above reason, the present study was under taken by using different crops and weed species from rice growing ecosystem.

\section{Materials and Methods}

The different crops and weed seeds from rice growing ecosystem were collected during summer, labeled and stored. In order to find out the host range of $R$. solani (RS-1) isolate, 26 plant species belonging to six families were grown in pots $(30 \mathrm{~cm}$ diameter) filled with sterilized soil. Seeds were sown in pot containing soil amended with $30 \mathrm{mg} \mathrm{N}, 9.7$ $\mathrm{mg} \mathrm{P}$, and $18.5 \mathrm{mg} \mathrm{K}$ per kilogram of soil using urea, single superphosphate, and murate of potash, respectively. The pots were inoculated with the sclerotia of the test fungus grown on PDA for 7 days at $28 \pm 1{ }^{\circ} \mathrm{C}$. The sclerotia were placed in the root zone with the help of sterile forceps for plant species belongs to family Leguminaceae, Malvaceae, Amaranthaceae and Fabaceae. For the plant species belongs to Graminaceae and Cyperaceae family the sclerotia were placed by opening the sheath region. Then the inoculated sheaths were covered with moist cotton and sprinkled with a few drops of sterile distilled water regularly for 24 hours to maintain $~ 100$ per cent humidity procedure was followed in accordance with Srinivas et al., (2014) and Adhipathi et al., (2013).

Inoculation was done in the evening and inoculated plants were sprayed with water next morning. Inoculated plants were kept under high humid conditions and were observed regularly for the appearance of the disease symptoms. The trial was carried out in the pots under glasshouse condition. Five seedlings were maintained in each pot. After inoculation of the plants, the pots were placed in glasshouse. The uninoculated control plants served as negative control. The symptoms were recorded 7 days after inoculation.

\section{Results and Discussion}

Host range studies indicated that pathogen $(R$. solani) successfully infected almost all the plant species. Typical sheath blight, root rot and bark peeling symptoms were started appearing 7 days after inoculation. Twenty five plant species belonging to six families were found infected and one plant species devoid of infection (Table 1). Diseased tissues of plants species belong to family Graminaceae crops (Maize, Wheat, Jowar, Bajra and Ragi), weeds (Torpedo grass, Crowfoot grass, Swollen fingergrass, Jungle rice, Jointed goatgrass, Viper grass, Knot grass, Bermuda grass and Hairy crab grass) and Cyperaceae (Umbrella sedge and Nutgrass) produced typical symptoms of sheath blight. 
Fig.1 Symptoms induced by Rhizoctonia solani on different crop plants

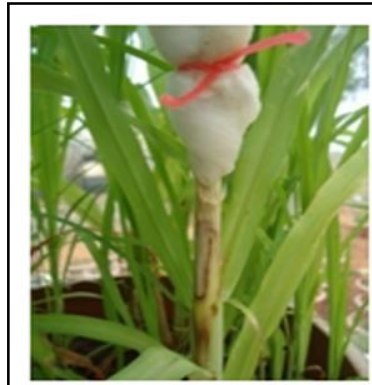

Bajra

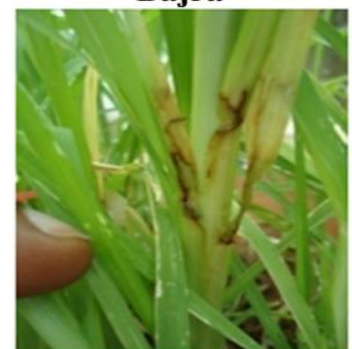

Ragi

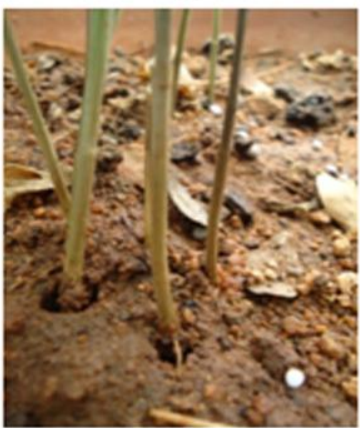

Blackgram

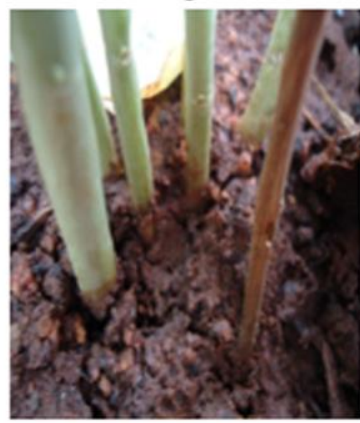

Cowpea

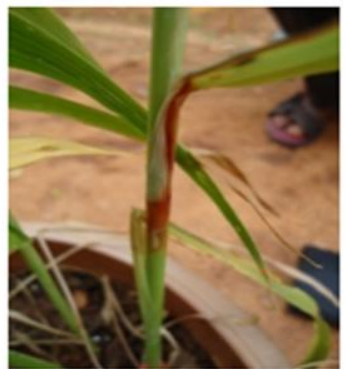

Jowar

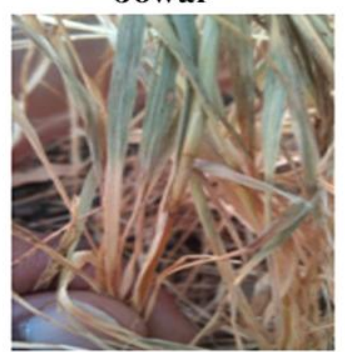

Wheat

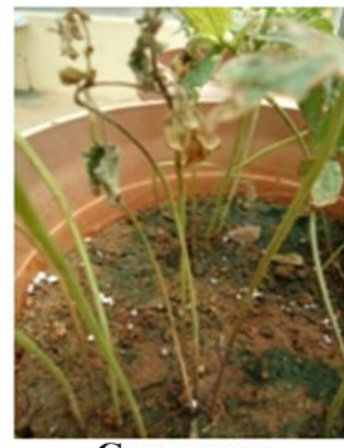

Greengram

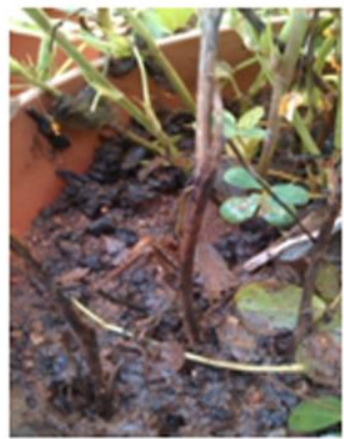

Groundnut

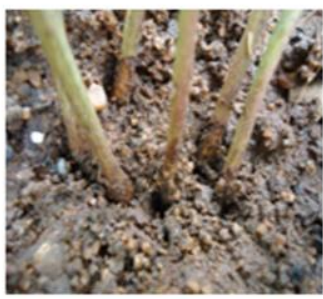

Cotton
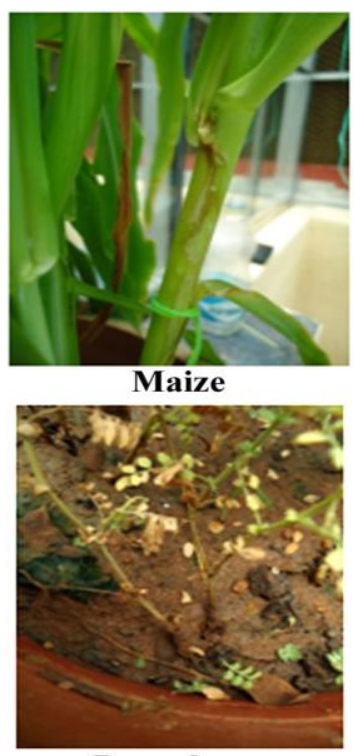

Bengalgram

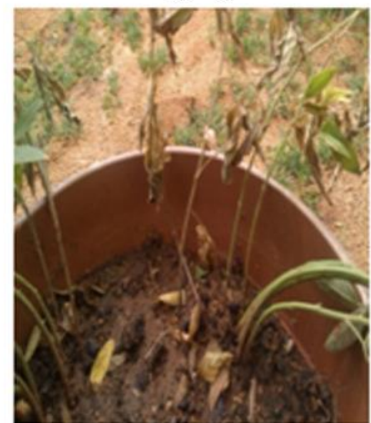

Redgram

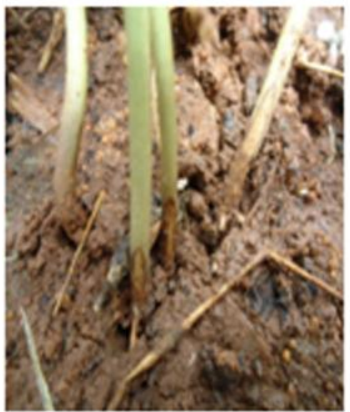

Soybean 
Fig.2 Symptoms induced by Rhizoctonia solani on different weeds hosts

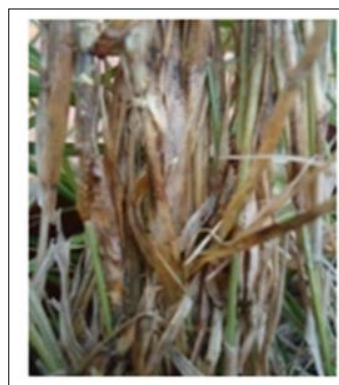

Bermuda grass

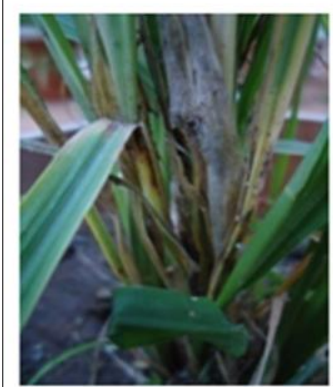

Jungle rice

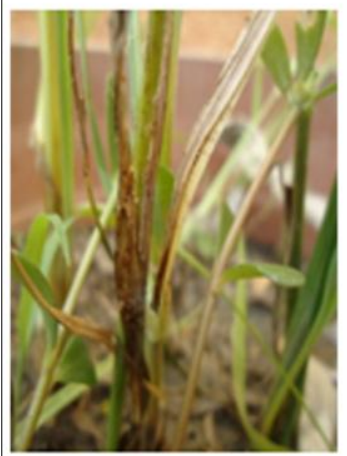

Nutgrass

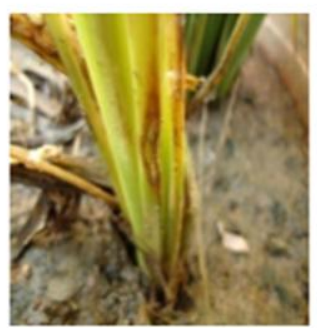

Umbrella sedge

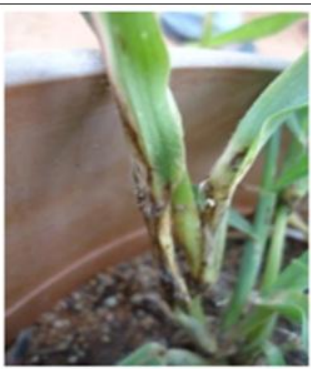

Crowfoot grass

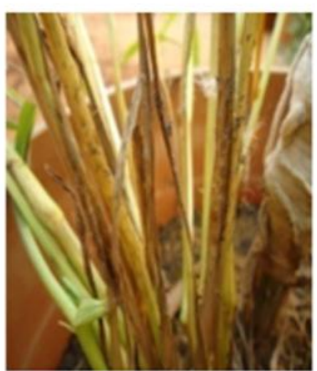

Jointed goatgrass

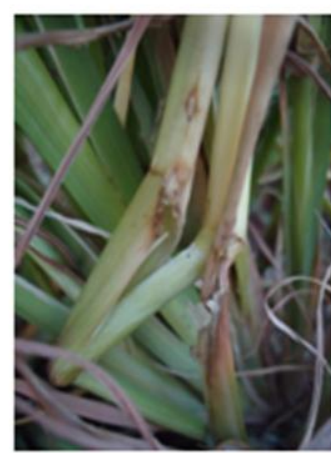

Swollen fingergrass

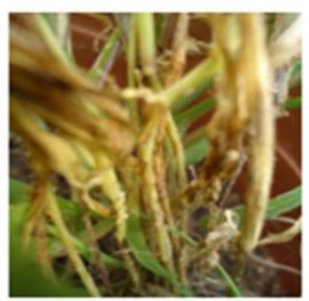

Viper grass

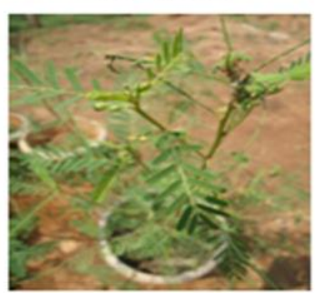

Indian joint vetch

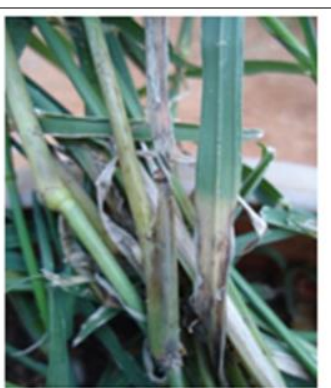

Hairy crab grass

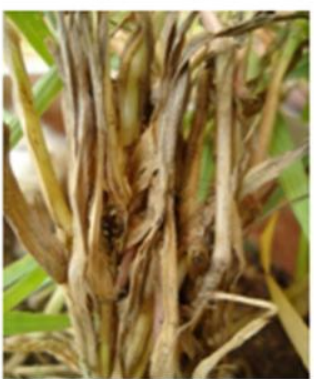

Knot grass

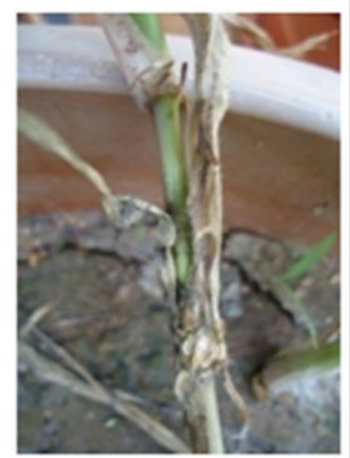

Torpedo grass

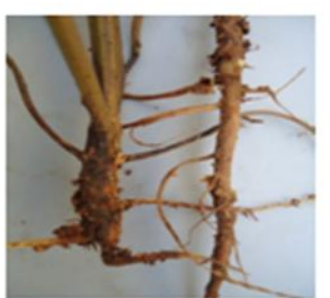

Spiny amaranth 
Fig.3 Survival of Rhizoctonia solani on different weeds hosts found during sheath blight survey

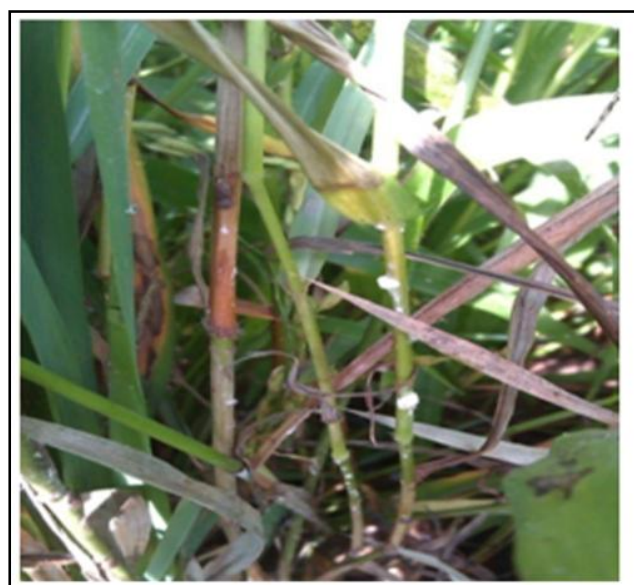

a. Knot grass

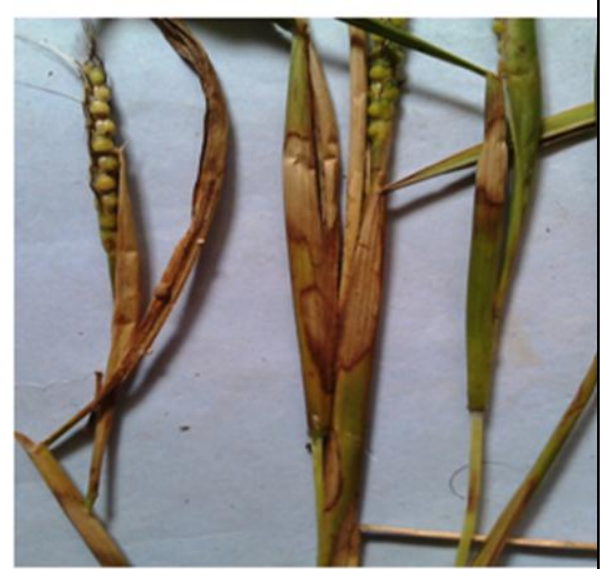

b. Jointed goatgrass

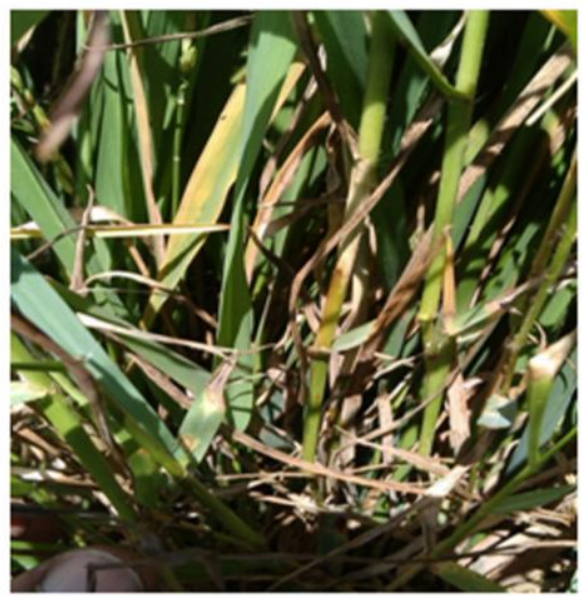

c.Napier spp.

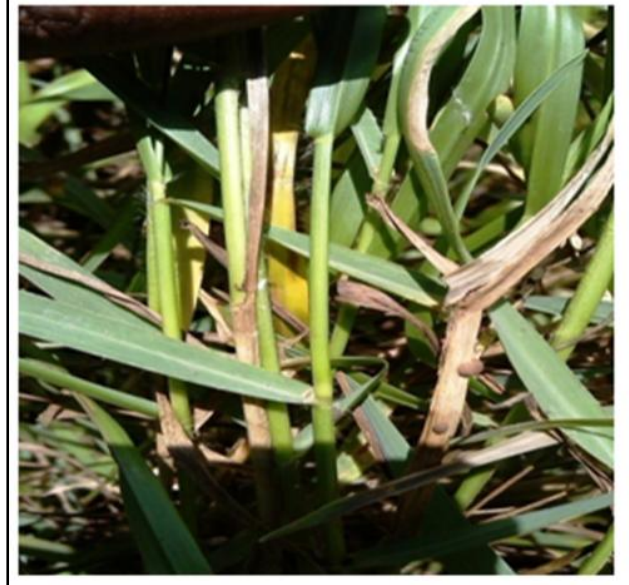

d. Torpedo grass

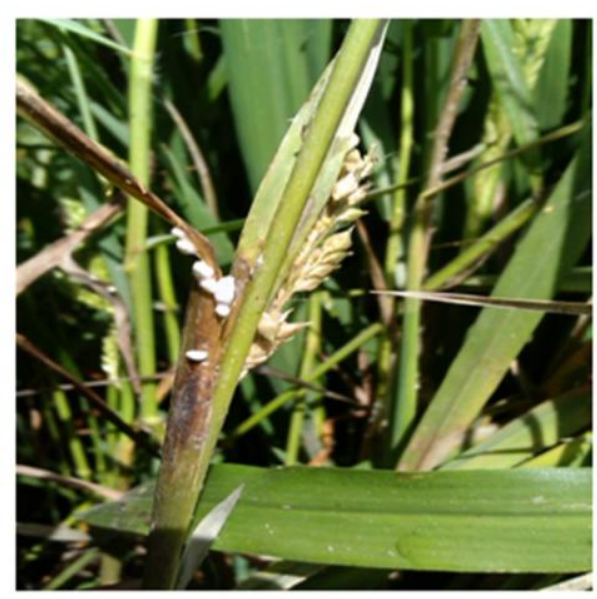

e. Jungle rice 
Table.1 Host range of Rhizoctonia solani and its cross infectivity with other cultivated crops and weeds

\begin{tabular}{|c|c|c|c|c|}
\hline Sl. No. & Common name & Botanical name & Family & Infection \\
\hline \multicolumn{5}{|c|}{ Cereal / Millets } \\
\hline 1. & Maize & Zea mays & Graminaceae & + \\
\hline 2. & Wheat & Triticum aestivum & Graminaceae & + \\
\hline 3. & Jowar & Sorghum bicolor & Graminaceae & + \\
\hline 4. & Bajra & Pennisetum typhoides & Graminaceae & + \\
\hline 5. & Ragi & Eleusine coracana & Graminaceae & + \\
\hline \multicolumn{5}{|c|}{ Pulses } \\
\hline 6. & Redgram & Cajanus cajan & Leguminaceae & + \\
\hline 7. & Greengram & Vigna radiata & Leguminaceae & + \\
\hline 8. & Blackgram & V. mungo & Leguminaceae & + \\
\hline 9. & Cowpea & V. unguiculata & Leguminaceae & + \\
\hline 10. & Bengalgram & Cicer arietinum & Leguminaceae & + \\
\hline & & Commercial crops & & \\
\hline 11. & Cotton (Bt, Non Bt) & Gossypium hirsutum & Malvaceae & + \\
\hline \multicolumn{5}{|c|}{ Oilseed crops } \\
\hline 12. & Groundnut & Arachis hypogaea & Leguminaceae & + \\
\hline 13. & Soybean & Glycine $\max$ & Leguminaceae & + \\
\hline \multicolumn{5}{|c|}{ Weeds } \\
\hline 14. & Torpedo grass & Panicum repens & Graminaceae & + \\
\hline 15. & Crowfoot grass & Dactyloctenium aegyptium & Graminaceae & + \\
\hline 16. & Swollen fingergrass & Chloris barbata & Graminaceae & + \\
\hline 17. & Jungle rice & Echinochloa colona & Graminaceae & + \\
\hline 18. & Umbrella sedge & Cyperus difformis & Cyperaceae & + \\
\hline 19. & Jointed goatgrass & Aegilops cylindrica & Graminaceae & + \\
\hline 20. & Viper grass & Dinebra retroflexa & Graminaceae & + \\
\hline 21. & Nutgrass & Cyperus rotundus & Cyperaceae & + \\
\hline 22. & Knot grass & Paspalum scorbiculata & Graminaceae & + \\
\hline 23. & Spiny amaranth & Amaranthus spinosus & Amaranthaceae & + \\
\hline 24. & Bermuda grass & Cynodon dactylon & Graminaceae & + \\
\hline 25. & Hairy crab grass & Digitaria sanguinalis & Graminaceae & + \\
\hline 26. & Indian joint vetch & Aeschynomene indica & Fabaceae & - \\
\hline
\end{tabular}

The fungus produced typical root rot and bark peeling symptoms in plant species belongs to family, Leguminaceae (Redgram, Green gram, Black gram, Cowpea, Bengalgram, Groundnut, Fabaceae (Soybean), Malvaceae (Cotton), Amaranthaceae (Spiny amaranthus). The fungus could not infect one weed species which belongs to family Fabaceae, Indian joint vetch (Aeschynomene indica) (Fig. 1 and $2)$. The fungus was re-isolated from all the infected plant species and produced typical $R$. solani characters on PDA. This proves that weeds and plants serve as collateral hosts and helped in the spread of the disease in next season. Survival of $R$. solani on weeds as a source of primary inoculum found during 
sheath blight survey is depicted in Figure 3.

The pathogen, $R$. solani has a wide host range infecting crops and weed plants. Typical sheath blight, root rot and bark peeling symptoms were started appearing 7 days after inoculation. Multinucleate Rhizoctonia sp. AG-1 IA causes symptoms viz., sheath blight, foliar blight, leaf blight, web-blight, head rot, bottom rot, and brown patch on different crops like rice (Oryza sativa L.), corn (Zea mays L.), barley (Hordeum vulgare L.), sorghum (Sorghum vulgare Pes.), potato (Solanum tuberosum L.), barnyard millet, common millet, soybean, peanut (Arachis hypogaea L.), lima bean, cabbage, leaf lettuce, stevia, orchard grass, crimson clover, tall fescue (Festuca arundiacea Schreb), turfgrass, creeping bentgrass, perennial ryegrass, gentian (Gentiana scabra), and camphor (Li and Yan, 1990; Sneh et al., 1998; Fenille et al., 2002 and Naito, 2004)

Host range studies indicated that pathogen $(R$. solani) successfully infected almost all the species. Twenty five plant species belonging to five families were found infected and one plant species devoid of infection. Goswami et $a l$. , (2010) found that thirty five crop species, namely wheat, rice, maize, prosomillet, foxtail millet, barley, sorghum, groundnut, soybean, sunflower, mustard, sesame, niger, safflower, chickpea. blackgram, lentil, grasspea, mungbean, cabbage, cauliflower, radish, stringbean, spinach, Indian spinach, Lady's finger, country bean, carrot, cucumber, white gourd, ribgourd, tomato, brinjal, potato and kangkon were tested against the isolates of Rhizoctnia solani under field and laboratory conditions and all were found infected by the fungus.

Srinivas et al., (2014) reported that rice isolate of $R$. solani infected 14 species belonging to three different families i.e., Amaranthaceae, Graminaceae and
Leguminaceae. Variability in disease symptoms, host range, and geographical location of $R$. solani isolates suggest that there are several strains of the species (Burpee and Martin, 1992). Rhizoctonia spp. has been classified according to 14 anastomosis groups (AGs, AG-1 to AG13 and AG-BI) (Carling et al., 2002). AG is a genetic feature that results in exchange of nuclei and the combining of different genotypes (Kataria et al., 1991 and Burpee and Martin, 1992).

The rice fungus $R$. solani infected 20 species which are from 11 families and observed that the sclerotia from diseased tissue of weed hosts produced typical symptoms of sheath blight on paddy plants (Kozaka, 1965 and Tsai, 1974). Kannaiyan and Prasad (1980) have listed 30 monocot weed species as host of Thanatephorus cucumeries (Rhizoctonia solani). This proves that weeds and plants serve as collateral hosts and helped in the spread of the disease in next season. Hence, keeping bunds clean of weeds will help in checking the disease spread from primary sources.

So, it is better recommended that weeding at timely intervals during crop season and selection of non-suitable crop helps in minimizing the disease in the next crop season. This was supported by (Tsai, 1974; Singh and Saksena 1980 and Goswami et al., 2010).

The management of this disease is possible only after the detailed study of different aspect of the pathogen. Recognizing the importance of the problem, the mode of survival of the pathogen on collateral hosts was studied in the conditions where crop is not sown for a season. This article represents the importance of weed management practices for minimizing the off season survival of the pathogen. 


\section{References}

Acharya, S., and Sengupta, P. K. 1998. Collateral hosts of rice sheath blight fungus Rhizoctonia solani. Oryza, 35: 89-90.

Adhipathi, P., Singh, V., and Meena, S. C. 2013. Virulence diversity of Rhizoctonia solani causing sheath blight disease in rice and its host pathogen Interaction. The Bioscan, 8(3): 949-952.

Anderson, N. A., 1982. The genetics and pathology of Rhizoctonia solani. Annu. Rev. Phytopathol. 20: 329-347.

Baker, K. F., 1970. Types of Rhizoctonia diseases and their occurrence. In: Parmeter JR, Jr, editor. Rhizoctonia solani: biology and pathology. Berkeley, CA: California University Press, pp.124-148.

Brown, E. A., and McCarter, S. M. 1976. Effect of a seedling disease caused by Rhizoctonia solani on subsequent growth and yield of cotton. Phytopathology. 66: 111-15.

Burpee, L. L., and Martin, B. 1992. Biology of Rhizoctonia species associated with Turfgrasses, Plant Dis., 76: 112-117.

Carling, D. E., Baird, R. E., Gitaitis, R. D., Brainard, K. A., and Kuninaga, S. 2002. Characterization of AG-13, a newly reported anastomosis group of Rhizoctonia solani. Phytopathology. 92: 893-899.

Carling, D. E., Leiner, R. H., and Kebler, K. M. 1987. Characterization of a new anastomosis group (AG-9) of Rhizoctonia solani. Phytopathology. 77: 1609-1612.

Conway, K. E., Maness, N. E., and Motes, J. E. 1997. Integration of biological and chemical controls for Rhizoctonia aerial blight and root rot of rosemary. Plant Dis. 81: 795-798.

Couch, H. B., 1995. Diseases of Turfgrasses Caused by Fungi. In: Couch HB, editor.
Diseases of Turfgrasses. 3rd ed. Malabar, FL: Krieger Publishing Company, pp. 21-199.

Escande, A. R., and Echandi, E. 1991. Protection of potato from Rhizoctonia canker with binucleate Rhizoctonia fungi. Plant Pathol. 40: 197-202.

Fenille, R. C., Luizde, S. N., and Kuramae, E. E. 2002. Characterization of Rhizoctonia solani associated with soybean in Brazil. Eur. J. of Plant Pathol. 108(8): 783-792.

Goswami, B. K., Bhuiyan, K. A. and Mian, I. H. 2010. Morphological and pathogenic variations in the isolates of Rhizoctonia solani in Bangladesh. Bangladesh $\mathrm{J}$. Agril. Res. 35(3): 375-380.

Kataria, H. R., Verma, P. R., and Gisi, U. 1991. Variability in the sensitivity of Rhizoctonia solani anastomosis groups to fungicides. Phytopathology. 153: $121-133$.

Kozaka, T., 1961. Ecological studies on sheath blight of rice of rice caused Pellicularia sasakii (Shirai) and its chemical control. Chugoko agric. Res. 20: 1-133.

Li, H. R., and Yan, S. Q. 1990. Studies on the strains of pathogens of sheath blight of rice in the east and south of Sichuan Province. Acta. Mycologica. Sinica. 9: 41-9.

Liu, Z., and Sinclair, J. B. 1991. Isolates of Rhizoctonia solani anastomosis group 2-2 pathogenic to soybean. Plant Dis. 75:682-687.

Naito, S., 2004. Rhizoctonia diseases: Taxonomy and population biology. Proceeding of the International Seminar on Biological Control of Soilborne Plant Diseases, Japan- Argentina Joint Study, Buenos Aires, Argentina, pp.1831.

Ogoshi, A., 1987. Ecology and pathogenicity of anastomosis and intraspecific groups of Rhizoctonia solani Kuhn. Annual 
Review of Phytopathology. 25: 125-43.

Ou, S. H., 1972. Rice diseases. First edition.

The common wealth Mycological Institute, Kew Survey, England. 368pp.

Singh, A., Singh, U. S., Willocquet, L., and Savary, S. 1999. Relationship among cultural/ morphological characteristics, anastomosis behaviour and pathogenecity of Rhizoctonia solani Kühn on rice. J. Mycol. Pl. Pathol. 29: 306-316.

Sneh, B., Burpee, L., and Ogoshi, A. 1998. Identification of Rhizoctonia species. The APS, St. Paul, Minesota.

Srinivas, P., Ramesh Babu, S. and Ratan, V., 2014, Role of sclerotia, plant debris and different hosts on survival of rice sheath blight pathogen, Rhizoctonia solani. Int.
J. Appl Biol. Pharm. 5(2): 29-33.

Tangonan, N. G., and Quebral, F. C. 1992. Host Index of Plant Diseases in the Philippines, 2nd edn. Los Banos, Philippines: University of the Philippines at Los Banos.

Wiseman, B. M., Neate, S. M., Keller, K. O., and Smith, S. E. 1995. Suppression of Rhizoctonia solani anastomosis group 8 in Australia and its biological nature. Soil. Biol. Biochem. 28: 727-732.

Yitbarek, S. M., Verma, P. R., and Morrall, R. A. A. 1987. Anastomosis groups, pathogenicity, and specificity of Rhizoctonia solani isolates from seedling and adult rapeseed/canola plants and soils in Saskatchewan. Can. J. Plant. Pathol. 9: 6-13.

\section{How to cite this article:}

Nagaraj, B.T., Gururaj Sunkad, D. Pramesh, M.K. Naik and Patil, M.B. 2017. Host Range Studies of Rice Sheath Blight Fungus Rhizoctonia solani (Kuhn). Int.J.Curr.Microbiol.App.Sci. 6(11): 3856-3864. doi: https://doi.org/10.20546/ijcmas.2017.611.452 